\title{
Structural and functional responses of the oligochaete and aeolosomatid assemblage in lowland streams: a one-way-pollution-modelled ecosystem
}

\author{
Maria V. LÓPEZ VAN OOSTEROM,,,$^{1,2^{*}}$ Carolina OCON, ${ }^{1,2,3}$ Laura C. ARMENDARIZ, ${ }^{1,3}$ \\ Alberto RODRIGUES CAPITULO ${ }^{1,2,3}$ \\ ${ }^{1}$ Instituto de Limnología Dr. Raúl A. Ringuelet, CC 712, CP 1900 La Plata, Buenos Aires; ${ }^{2}$ Consejo Nacional de Investigaciones \\ Científicas y Técnicas (CONICET-CCT-La Plata), La Plata, Buenos Aires; ${ }^{3}$ Facultad de Ciencias Naturales y Museo, Universidad \\ Nacional de La Plata, Buenos Aires, Argentina \\ *Corresponding author: vanesa@ilpla.edu.ar
}

\begin{abstract}
We investigated the responses of the assemblage of Oligochaeta and Aeolosomatidae to organic pollution; comparing taxonomic richness, diversity, abundance, and diet of the individuals inhabiting two lowland streams with different degrees of anthropic impact (the Rodriguez and the Carnaval) belonging to the Rio de la Plata basin, Argentina. The physicochemical parameters in the Rodriguez Stream indicated a strong deterioration of the water quality compared to that of the Carnaval. A canonical-correlation analysis indicated that the Tubificinae, Megadrili, Enchytraeidae, and Rhyacodrilinae were more closely associated with the Rodriguez Stream; whereas the Naidinae, Pristininae, and Opystocystidae were more highly represented in the Carnaval. The diversity and taxonomic richness in the Rodriguez Stream exhibited significant differences from those of the Carnaval $(P<0.001)$, but the abundance was not different between the two sites. Schoener's index revealed the higher degree of dietary overlap of the two streams because all the species analysed consumed a high proportion of detritus, especially the organisms in the Rodriguez. In the Carnaval Stream a higher number of alimentary items were consumed, and mainly by the Naidinae. This difference, probably reflecting the greater availability of this resource at sites impacted by organic pollution, underscores the fundamental role of oligochaetes in the food webs of aquatic ecosystems. The combined use of structural and functional parameters enables a more comprehensive view of how these lotic systems function and as such provides information that will serve to design tools for the management of such temperate environments.
\end{abstract}

Key words: Oligochaeta, lowland stream, organic pollution, diet.

Received: November 2014. Accepted: February 2015.

\section{INTRODUCTION}

Oligochaetes often the most diverse and abundant group of benthic invertebrates found in freshwater systems (Wetzel et al., 2006) inhabit all types of substrata, but reach a higher density and taxonomic richness mainly in fine sediments (Marchese, 2009). These annelids participate in the trophic networks of aquatic systems as a feeding resource for turbellarians, hirudineans, chironomids, Tanypodinae, crayfish, amphipods, amphibians, fish, and even birds (Ezcurra de Drago et al., 2007); while the oligochaetes themselves feed on subsurface sediments, thus recycling deposited material. At high worm densities, this form of reworking can modify the structure of sediments considerably (Krezoski and Robbins, 1985). Because of their ecologic prevalence and presence in all environments, the oligochaetes are widely utilized as indicators of the environmental condition of freshwater ecosystems and, among other parameters, the trophic characteristics of bodies of water (Lafont et al., 2001; Krodkiewska and Michalik Kucharz, 2009). Studies on oligochaetes have thus far been focussed on their use as bioindicators of water quality through their distribution in relation to environmental con- ditions (Brinkhurst and Kennedy, 1965; Alves et al., 2006; Azrina et al., 2006; Martin et al., 2008).

A deterioration of the water quality and a contamination of both underground and surface water are the major problems faced in the administration of water resources worldwide (Jouravlev, 2001; Kaika and Page, 2003). The bodies of running water in the pampean plain are characterized by their low discharge as a result of the typically shallow gradient, which gentle slope increases the water-residence time (Bauer et al., 2002; Rodrigues Capitulo et al., 2010). At the same time, the input of nutrients, organic matter, and toxic compounds is the most frequent form of pollution-induced disturbance in these running-water systems (AAAGOSBA-OSN-ILPLA-SHN, 1997). Although within the Argentine pampean plain environmental restoration projects are in progress in the Matanza Riachuelo basin in general (ACUMAR, http://www.acumar.gov.ar/, accessed December 2014) and on the Reconquista River in particular (UNIREC, http://www.comirec.gba.gov.ar/on, accessed December 2014), preventive-management practices and effluent-control measures still need to be instigated in most of the rivers and streams there in order to characterize and 
eventually reduce the impact of human activity on the environment.The effects of anthropic disturbances on these lentic and lotic systems can be assessed by measuring changes in the structural parameters of informative communities such as biodiversity (i.e., both species diversity and taxonomic richness). Human impact also affects the community functional parameters such as feeding habits, diet, and trophic relationships (Metcalfe-Smith, 1996) by modifying the proportions of alimentary resources in the environment. For example, an increase in organic matter can be reflected in an enhanced consumption of that resource by the detritivorous organisms. Warfe and Barmuta (2006) explored the effect of community structure on foodweb dynamics. The interest in this kind of study, where structural and functional parameters, such as the invertebrate diet, are taken into account, has increased in recent years (Tomanova et al., 2006). The fundamental biological relevance of such research, however, is in marked contrast to our limited knowledge of the structural and functional responses of the oligochaetes. Most fundamentally, an understanding of the feeding biology of aquatic oligochaetes in particular is necessary in order to make a correct interpretation of the various biologic processes in general (Rodríguez et al., 2001). Oligochaete species richness is directly related to food availability (Collado and Schmelz, 2001) and quality (Pasteris et al., 1994), substrate type (Bletter et al., 2008), oxygen availability (Nijboer et al., 2004), and biologic interactions (Darrigran et al., 1998). Within this context, the response of the oligochaete assemblage to organic contamination might consist in either a decrease or an increase in their richness and diversity at those sites with strong anthropic impact.

The relevance of the present study lies in the combined use of structural and functional parameters as a means of evaluating temperate streams with different degrees of anthropic impact. The aim of this work was thus to study the responses of the assemblage of oligochaetes and aeolosomatids to organic pollution and to analyse and compare the taxonomic richness, species diversity, abundance, and diet of the oligochaetes in two representative lowland streams with different degrees of human influence. The information obtained here should facilitate the creation of tools for the management of temperate lotic systems in this region that can thereafter be extrapolated to comparable environments elsewhere.

\section{METHODS}

\section{Study area}

The two streams studied are located in the pampean region within the Río de la Plata basin, Argentina. Pampean grassland is the typical biome in the pampas, a steppe composed of gramineous species (Cabrera, 1971). The climate is temperate and humid with an annual aver- age temperature of $18^{\circ} \mathrm{C}$ and an annual average rainfall of $900 \mathrm{~mm}$ (Giorgi et al., 2005). Lowland streams originate in small depressions and are characterized by a low flow rate as a result of the gradual slope of the surrounding terrain, by high levels of suspended solids, and by a silty sediment in the benthos (Rodrigues Capítulo et al., 2010).Three sampling sites were selected (Fig. 1), two located in the Rodríguez Stream, referred to here as R1 (34 $53^{\prime} 59.89^{\prime \prime} \mathrm{S} ; 58^{\circ} 3^{\prime} 44.26^{\prime \prime} \mathrm{W}$ ) and R2 (34 52' 42.95" $\left.\mathrm{S} ; 58^{\circ} 2^{\prime} 7.79^{\prime \prime} \mathrm{W}\right)$ and one in the Carnaval Stream, indicated as C (34 $\left.53^{\prime} 8.67^{\prime \prime} \mathrm{S} ; 58^{\circ} 5^{\prime} 23.43^{\prime \prime} \mathrm{W}\right)$. The three sites were established within the middle reach of the two streams. The total length of the Rodríguez Stream is about $22 \mathrm{~km}$, it being a second-order watercourse (Fig. 1). A dam located upstream from Site R1 has created a small artificial pond in a private neighbourhood, favouring water retention and modifying the discharge downstream. Both horticulture and extensive cattle raising are carried out in this area. Site R2 is located in an urban area. Both sites, R1 and R2 are situated downstream from the effluent discharged from a slaughterhouse and meat-packing company (Bauer et al., 2002). The lower reach of the stream is channelized and was not included in this study. The Carnaval is also a second-order stream, with a total length of about $14.5 \mathrm{~km}$. The main land use in the upper and middle sections of the basin are related to agriculture (flower and fruit cultures), although wastelands are also present. The lowest section of the stream, however, is surrounded by urban settlements and some industrial activities (Banda Noriega and Ruiz de Galarreta, 2002).

\section{Physicochemical parameters}

At each site, the following physical and chemical variables were measured: dissolved-oxygen concentration (DO $\left.\mathrm{mgL}^{-1}\right)$, temperature $\left({ }^{\circ} \mathrm{C}\right), \mathrm{pH}$, conductivity $\left(\mu \mathrm{Scm}^{-1}\right)$, and turbidity (NTU) with a HORIBA (U-10) portable water-quality meter. Triplicate water samples $(\mathrm{n}=45)$ were taken for the analysis of biologic oxygen demand $\left(\mathrm{BOD}_{5}, \mathrm{mgL}^{-1}\right)$ and chemical oxygen demand $\left(\mathrm{COD}, \mathrm{mgL}^{-1}\right)$. At the same time, water samples were filtered through sintered-glass-fibre filters (Whatman GF/F, Whatman International Ltd., Maidstone, UK) and then analysed for $\mathrm{N}^{-\mathrm{NH}_{4}}{ }^{+}\left(\mathrm{mgL}^{-1}\right), \mathrm{N}_{-} \mathrm{NO}_{2}^{-1}\left(\mathrm{mgL}^{-1}\right), \mathrm{N}^{-\mathrm{NO}_{3}}{ }^{-1}$ $\left(\mathrm{mgL}^{-1}\right), \mathrm{P}_{-} \mathrm{PO}_{4}^{-3}\left(\mathrm{mgL}^{-1}\right)$, total suspended solids (TSS, $\mathrm{mgL}^{-1}$ ), and total organic suspended solids (organic TSS) by standard methods. Benthic-sediment samples were collected in triplicate with a $10 \times 10-\mathrm{cm}\left(100-\mathrm{cm}^{2}\right)$ Ekman dredge and a total of 45 samples analysed. The organic matter in the sediment, calculated by weight loss after ignition at $500^{\circ} \mathrm{C}$ for $4 \mathrm{~h}$ from a subsample $(20 \mathrm{~g}$ net weight), was expressed as a percentage of the total sediment weight, as were separately the fine (from 62 to $500 \mu \mathrm{m}$ in diameter: FPOM) and coarse ( $>500 \mu \mathrm{m}$ in diameter: CPOM) sub-fractions of the organic matter. All 
the analyses were performed as indicated by the American Public Health Association (APHA, 1998). The granulometric analysis was made following the Stokes principle, based on the speed of particle sedimentation (Folk, 1959). The vegetal coverage was assessed by measuring the area within the reach occupied by each type of plant according to Feijóo and Menéndez (2009).

A sample of the benthic sediment was collected at each site during a single additional sampling (December 2010) for the determination of:

- heavy metals: $\mathrm{Pb}, \mathrm{Zn}, \mathrm{Ni}, \mathrm{Cr}, \mathrm{Cd}, \mathrm{Cu}$;

- herbicides: 2,4-D, MCPA, MCPP, Dicamba ${ }^{\mathrm{TM}}$, Silvex Acid $^{\mathrm{TM}}, 2,4-\mathrm{DB}$;

- organochlorine pesticides: $\alpha-, \beta-, \delta$-, and $\gamma-\mathrm{HCH}$, heptachlor, heptachlor epoxy, aldrin, $\alpha$ - and $\delta$-chlordane, dieldrin+DDE, endrin, $\alpha$ - and $\beta$-endosulfan, endrin aldehyde, endosulfan sulphate, endosulfan I, endrin ketone, DDT;
- organophosphate pesticides: EPTC, ethyl N, vermolate, molinate, propazine, terbufos, malathion, methyl and ethyl parathion, dichlorvos, ethoprop, demeton, diazinon, disulfoton, chlorpyrifos, dichlorofenthion, trichloronate, tetrachlorvinphos, Tokuthion $^{\mathrm{TM}}$, fensulfothion, Bolstar ${ }^{\mathrm{TM}}$, azinphosmethyl, coumaphos.

Samples were preserved in the cold until the time of analyses, those being performed by standard methods (Environmental Protection Agency, 1995). Samples were prepared by methods 3111, SW 846 B and C for metals; 6630 B, SW 846 for pesticides; and 8321, SW 846 (involving high-performance liquid chromatography and ultraviolet light) for herbicides. The registered values were compared with the Canadian Environmental-Quality Guidelines (CCME, 2003), since no guideline levels exist for these pesticides in the benthic sediments of the area studied (Di Marzio et al., 2010).

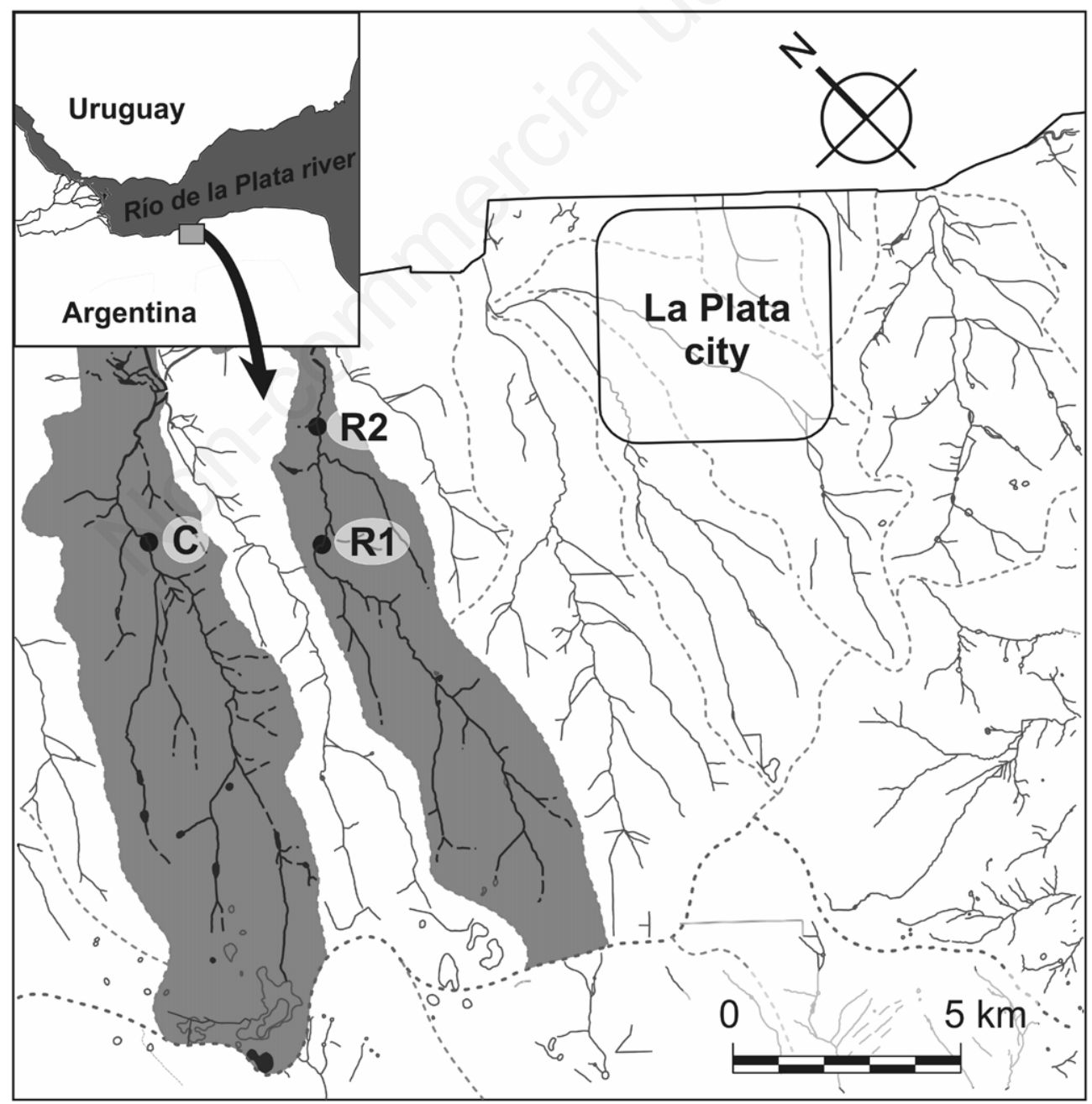

Fig. 1. Map of the study area showing the streams and the locations of the sampling sites. 


\section{Assemblage of oligochaetes and aeolosomatids}

At each sampling site we studied two habitats, the sediments and the aquatic macrophytes; whenever possible sampling the same microhabitats at all the sampling sites. Five samplings were carried out in November 2009, March 2010, June 2010, September 2010, and December 2010. For the sediment habitat three replicates were collected with an Ekman dredge $\left(100 \mathrm{~cm}^{2}\right)$ for a total of 45 samples. The worms present on the macrophytes were collected according to Barbour et al. (1999). An area of $625 \mathrm{~cm}^{2}$ was delimitated with a plexiglas square and the macrophytes contained in the square sampled with a sieve of pore size $250 \mu \mathrm{m}$. The samples, collected in triplicate, totalled 33 for the macrophytes, but were unequally distributed since the species richness changed markedly between the two streams and throughout the year. Both the submerged and floating aquatic macrophytes were collected at the sampling sites. The macrophytes present in the Carnaval Stream were Alternanthera philoxeroides(Martius) Grisebach, Hydrocotyle bonariensis, and Sagittaria montevidensis Chamisso and Schlechtendal; while those collected in the Rodríguez Stream were H. bonariensis, A. philoxeroides, and Ludwigia peploides (Kunth) Raven at Site R1 and H. bonariensis and A. philoxeroides at Site R2.

All samples were fixed in situ with $5 \%(\mathrm{v} / \mathrm{v})$ formaldehyde. In the laboratory, the samples were washed on a sieve of pore size $250 \mu \mathrm{m}$ (benthos and macrophytes) and stained with erythrosin-B. The annelids were separated under a stereomicroscope and finally identified by light microscopy through the use of standard morphological keys (Brinkhurst and Marchese, 1992; International Commission on Zoological Nomenclature, 2007). The Enchytraeidae were not identified at the species level since the appropriate identification keys were not available. The material collected was preserved in $70 \%(\mathrm{v} / \mathrm{v})$ aqueous ethanol. The organisms were counted and their average density expressed as individuals per square meter $\left(\mathrm{indm}^{-2}\right)$ for each sampling site. Shannon's diversity index ( $\left.\mathrm{H}^{\prime}\right)$ and taxonomic richness were also calculated (Hammer et al., 2001).

\section{Biofilm sampling}

At each sampling site 10 subsamples were collected by pipetting the surface layer of the sediment $(5-10 \mathrm{~mm})$ and fixed in $4 \%(\mathrm{v} / \mathrm{v})$ formaldehyde to analyse the composition of the epipelic biofilm (Gómez and Licursi, 2001). A total of 45 samples were processed. Of the epiphyton, 33 samples were collected at each sampling site, comprising three replicates of each plant (Alternanthera philoxeroides, Hydrocotyle bonariensis, Sagittaria montevidensis, and Ludwigia peploides) and then registered according to the date and their presence and coverage. Three stems of each macrophyte along with the leaves (at stem lengths of $c a .10 \mathrm{~cm}$ ) were cut at random, then freed of all fragments by sonication (a 6-min cycle), and finally preserved in $4 \%(\mathrm{v} / \mathrm{v})$ formaldehyde. We calculated the vegetal area of each macrophyte (stem and leaves).

The cell density per square centimeter was estimated by microscopy through counting in a Sedgwick-Rafter chamber (APHA, 1989) and the proportion of each algal category estimated. The biofilm was classified according to the following taxonomic categories: Bacillariophyceae, Chlorophyta, Euglenophyta, Cyanobacteria, Ciliata, and Fungi. For each biofilm the average ratio of epipelon to epiphyton was determined at each site and for each sampling date.

\section{Analysis of gut contents}

For each sampling date, up to 10 individuals of each taxon, totalling 288 organisms, were dissected under the stereomicroscope. The foreguts were separated and the contents removed and placed in vials with Bengal's rose colorant for $24 \mathrm{~h}$ (Rublee and Partusch-Talley, 1995). The samples were then transferred to distilled water, homogenized, and centrifuged for ten min. The sedimented material was mounted on slides and examined by microscopy at 400X magnification. For each sample, 15 fields per slide were randomly selected and the area covered by each item measured with a graduated eyepiece. On the basis of those data, the relative abundance of each item was expressed as a percent of the area occupied by the total gut contents (Díaz-Villanueva and Albariño, 1999).

\section{Statistical analysis}

One-way ANOVA was used to assess differences in physicochemical parameters among the sites. All data (except $\mathrm{pH})$ were $\log$-transformed $\left[\log _{10}(\mathrm{x}+1)\right]$ before the analysis in order to normalize the data. A Tukey test was applied in those cases where significant differences were found. Multivariate analysis was performed to examine the ordination of the sampling sites based on the previously standardized physicochemical parameters. An a-priori detrended-correspondence analysis was applied to obtain the length of the data-scattering gradient for the taxa within the environmental space, because this result allowed the selection between a linear or a unimodal method. A direct method, the canonical-correspondence analysis (CCA), was chosen because the gradient length was higher than 2 standard-deviation units (Ter Braak and Smilauer, 2002). The environmental variables were automatically excluded from the analysis if multicolinearity was observed by a varianceinflation factor greater than 10 and were manually excluded when $\mathrm{P}>0.05$ (no explanatory variables for the observed species distribution). Significant relationships were tested by the Monte-Carlo procedure at 199 permutations (Ter Braak and Smilauer, 2002).

Macrophyte architecture produces strong effects on 
the macroinvertebrate community so as to result in a diverse and highly abundant freshwater-fauna assemblage associated with the most structurally complex type of plant (Warfe and Barmuta, 2006). Accordingly, the total abundance, diversity, and species richness of the oligochaetes and the aeolosomatids were analysed in the vegetation samples as well as the sediment. Because of the specific variation in macrophytes recorded over the study period and between sampling sites, the associated assemblages could not be compared (Warfe and Barmuta, 2006; Ferreiro et al., 2011), although such a determination was possible in the sediment samples. A Student $t$-test was applied to compare the samples; and when the data were not normally distributed and/or had unequal variances, they were analysed by the Mann-Whitney Rank-Sum Test. The trophic-niche overlap was calculated by means of the Schoener Proportional Similitude Index (Schoener, 1970). Schoener' index, SP, was calculated as:

$$
S P(1,2)=1-\frac{1}{2} \sum(p 1 j-p 2 j)
$$

Where $p 1 j$ and $p 2 j$ are the estimated proportions by frequency of prey $i / j$ in the diets of species 1 and 2 , respectively. The index ranges from 0 , indicating no dietary overlap, to a maximum overlap of 1 , when all prey items are found in equal proportions. A value of 0.6 in the SP index was established as the threshold of significant dietary similitude (Wallace, 1981). A dendrogram was constructed with the values of the SP index through the complete-linkage method (Sokal and Rohlf, 1995). The similarity-percentage method (SIMPER) was then used to analyse the percentage of contribution of each alimentary item to each of the groups within a cluster (Clarke and Warwick, 2001).

For selectivity of algal categories the electivity coefficient, E, (Ivlev, 1961) was applied. E was given by:

$\mathrm{E}:\left(\frac{P i-P a}{P i+P a}\right)$

where

$\mathrm{Pi}=$ proportion $(\%)$ in gut contents;

$\mathrm{Pa}=$ proportion (\%) in biofilm.

Zero indicates non-selective feeding and values from -1 to 0 avoidance, with the values from 0 to +1 denoting preference.

\section{RESULTS}

The results of the one-way ANOVA indicated significant differences $(\mathrm{P}<0.05)$ between sites for the TSS, organic TSS, FPOM, CPOM, conductivity, $\mathrm{DO}, \mathrm{BOD}_{5}$, $\mathrm{P}_{-} \mathrm{PO}_{4}^{-}, \mathrm{N}-\mathrm{NO}_{2}^{-}$, and N-NH${ }_{4}^{+}$. Tukey's test confirmed the reality of these significant differences between the Carnaval-stream site and both the Rodríguez sites, except for $\mathrm{N}-\mathrm{NO}_{2}^{-}$, where no significant differences were found between sites $\mathrm{C}$ and $\mathrm{R} 1$ or $\mathrm{R} 2$ ( $\mathrm{P}>0.05$; Tab. 1). The vegeta- tion cover in both streams was less than $20 \%$. Although the mean depth at all three sites was lower than $20 \mathrm{~cm}$, Site R2 was significantly shallower than the Carnavalstream site (Tab. 1). The concentrations $\left(\mu \mathrm{g} \mathrm{kg}^{-1}\right)$ of $\mathrm{Zn}$, $\mathrm{Ni}, \mathrm{Cr}, \mathrm{Cd}, \mathrm{Cu}$, and $\mathrm{Pb}$ in the sediment of both the Carnaval and Rodríguez streams were lower than the maxima indicated in the Canadian guidelines, as were the organochlorine-pesticide levels in the Carnaval stream. Three different organochlorine pesticides, however, were detected at excessive levels in the Rodríguez stream: $\alpha$ $\mathrm{HCH}$, with values of $60 \mu \mathrm{g} \mathrm{kg}^{-1}$ and $330 \mu \mathrm{g} / \mathrm{kg}$ at sites R1 and R2, respectively; DDD (4, ' - -DDD), with values of $230 \mu \mathrm{g} \mathrm{kg}^{-1}$ at Site R1; and $\alpha$-endosulfan, with values of $120 \mu \mathrm{g} \mathrm{kg}^{-1}$ at Site R1, plus $\beta$-endosulfan, with values of $370 \mu \mathrm{g} / \mathrm{kg}$ at Site R2. A first CCA (Fig. 2) evaluated fifteen physicochemical parameters that were tested for inflation and $\mathrm{P}$ value. In the final analysis, the following variables were excluded because of colinearity or a $\mathrm{P}>0.05$ : organic TSS, temperature, $\mathrm{CPOM}, \mathrm{pH}$, turbidity, $\mathrm{COD}, \mathrm{N}_{-} \mathrm{NO}_{3}^{-}$, and $\mathrm{N}^{-} \mathrm{NO}_{2}^{-}$. The most informative variables for the observed species distribution were DO, TSS, P- $\mathrm{PO}_{4}^{-}$, conductivity, N-NH${ }_{4}^{+}, \mathrm{FPOM}$, and $\mathrm{BOD}_{5}$. The first axis of the analysis explained $47.6 \%$ of the total cumulative variance and the second $17.6 \%$. The MonteCarlo permutation test demonstrated that all the canonical axes were significant, with values of $\mathrm{F}=4.795$ and $\mathrm{P}=0.002$ for the first axis and $\mathrm{F}=1.993$ and $\mathrm{P}=0.002$ for all axes. The CCA analysis evidenced an environmental gradient represented by Axis 1, where the parameters related to organic pollution increased from left to right. The R1 and R2 sites were correlated with these parameters; while their associated taxa were Tubificinae, Megadrili, Rhyacodrilinae, and Enchytraeidae. Samples corresponding to the Carnaval site were most closely associated with higher concentrations of DO and suspended solids and were correlated with the Naidinae and Pristininae subfamilies and the Opistocystidae family.

We studied a total of 33 taxa among the Naididae, Opistocystidae, Enchytraeidae, Megadrili, and Aeolosomatidae. In the Carnaval Stream the Naidinae and Pristininae were the most abundant taxa at densities of 12,400 and 9700 ind $\mathrm{m}^{-2}$, respectively (Tab. 2, Supplementary Tab. 1 ). Within the Naidinae, the species with densities greater than 1,000 ind $\mathrm{m}^{-2}$ were Nais variabilis, N. communis, $N$. pardalis, Slavina appendiculata, and Dero pectinata. The total mean density of the Tubificinae was greater than 1300 individuals, mainly represented by Aulodrilus pigueti. At both the sites of the Rodríguez Stream the Tubificinae and Enchytraeidae were the most abundant, but with densities lower than 1700 ind $\mathrm{m}^{-2}$ (Supplementary Tab.1) The species with the greatest abundance among the Tubificinae was identified as Limnodrilus hoffmeisteri, whereas the Enchytraeidae could not be determined at a species level. The Carnaval stream exhibited higher values for the abundance, 
richness, and diversity of the oligochaete assemblage than did the Rodríguez stream. In the Carnaval stream the total oligochaete abundance varied from $140 \mathrm{ind}^{-2}$, associated with $A$. philoxeroides and recorded during November 2009 , to more than 17,500 ind $\mathrm{m}^{-2}$ in the sediment sampled during September 2010 (Fig. 3a; Supplementary Tab. 1); whereas in the Rodríguez stream the abundance, associated with $A$. philoxeroides, varied from 2 ind $\mathrm{m}^{-2}$ in March 2010 to more than 7200 ind $\mathrm{m}^{-2}$ in the sediment in September 2010 (Fig. 3b, Supplementary Tab. 1).

The taxonomic richness varied between 1 and 18 for both of the streams in March 2010 (Fig. 3 c,d), while the Shannon diversity index varied from 0 at Site R2 of the Rodríguez Stream (Fig. 3f) to 2182 (principally H. bonariensis) in the Carnaval Stream in December 2010 (Fig. $3 \mathrm{e})$. The results of the $t$ tests on the sediment samples from the two streams revealed significant differences in diversity $(\mathrm{P}<0.001)$ and species richness $(\mathrm{P}<0.001)$ though no significant differences were found in the total oligochaete abundance $(\mathrm{P}=0.056)$. A total of 288 individuals from the three sampling sites were dissected. In the Carnaval stream a higher number of consumed alimentary items (mainly by Naidinae) were registered, while the animal remains found (ostracod larval nauplii) were found in the intestinal contents of Chaetogaster diastrophus. At both sites of the Rodríguez Stream the number of consumed alimentary items was low and was mainly represented by detritus, fungi, and mineral remains. There, only two specimens of the Naidinae belonging to two species (Dero (Dero) digitata and Dero (Dero) pectinata) were dissected from Site R1. A low overall proportion of algae, represented mainly by Bacillariophyceae, were also observed among most of the taxa studied, though with approximately a 50\% abundance occurring in the epipelon. The Chlorophyta, Fungi, and Ciliata exhibited a low percent abundance within the environment (Tab. 3). At both sites of the Rodríguez Stream the Cyanobacteria were plentiful, representing more than $50 \%$ of the biofilm, although these taxa were not present in the guts of the oligochaetes (Tab. 3). Although six algal categories were observed in the biofilm, only four were recorded in the gut contents. The electivity coefficients with respect to the different food categories for the oligochaetes of the Carnaval Stream indicated no selection by the Naidinae of Bacillariophyceae $(\mathrm{E}=-0.912)$, Chlorophyta $(\mathrm{E}=-0.818)$, and Ciliata $(E=0.999)$, but instead preferences for Fungi $(E=0.875)$. The Pristininae, Tubificinae, and Aeolosomatidae likewise exhibited no selectivity for Bacillariophyceae $(\mathrm{E}=1.000)$. At Site R1 of the Rodríguez Stream, the Tubificinae ignored the Bacillariophyceae $(\mathrm{E}=-0.90)$, but rather had a

Tab. 1. Mean value \pm standard deviation of physicochemical and morphologic parameters at the study sites with results from the oneway ANOVA for comparisons among the three sites: C, Carnaval Stream; R1 and R2, Rodríguez Stream. NP, the nonparametric tests for vegetal coverage, depth, organic matter (both coarse and fine) and $\mathrm{P}_{-} \mathrm{PO}_{4}^{-}$, with the critical value corresponding to $\mathrm{H}$.

\begin{tabular}{|c|c|c|c|c|}
\hline \multirow[t]{2}{*}{ Variables } & \multirow[b]{2}{*}{ C } & \multirow[b]{2}{*}{ R1 } & \multicolumn{2}{|r|}{ ANOVA } \\
\hline & & & R2 & C-R1-R2 (F, P values) \\
\hline Temperature $\left({ }^{\circ} \mathrm{C}\right)$ & $20.7 \pm 5.54$ & $19.7 \pm 5.34$ & $18 \pm 4.21$ & Not tested \\
\hline Vegetal coverage $(\%)$ & $12 \pm 10$ & $10 \pm 8$ & $10 \pm 11$ & $1.02,0.06(\mathrm{NP})$ \\
\hline Depth (m) & $0.19 \pm 0.09$ & $0.11 \pm 0.15$ & $0.14 \pm 0.15$ & $9.93,0.007(\mathrm{NP})$ \\
\hline TSS $\left(\mathrm{mg} \mathrm{L}^{-1}\right)$ & $74.1 \pm 19.4$ & $24.1 \pm 8.59$ & $56.8 \pm 5.02$ & $7.76,0.011$ \\
\hline TSS organic (\%) & $17.0 \pm 3.97$ & $65.6 \pm 5.08$ & $38.1 \pm 25.2$ & $11.2,0.002$ \\
\hline FPOM $(\%)$ & $3 \pm 1.13$ & $15 \pm 10.6$ & $12 \pm 7.8$ & $9.98,0.007(\mathrm{NP})$ \\
\hline CPOM (\%) & $5 \pm 3.5$ & $19 \pm 9.2$ & $13 \pm 11.3$ & $6.51,0.012$ \\
\hline Sand $(\%)$ & $39.5 \pm 16.8$ & $57.1 \pm 21.5$ & $34.5 \pm 34.5$ & $2.41,0.17$ \\
\hline Silt (\%) & $33.2 \pm 9.7$ & $14.2 \pm 3.6$ & $42.1 \pm 42.1$ & $5.54,0.063(\mathrm{NP})$ \\
\hline Clay (\%) & $27.3 \pm 10.8$ & $28.7 \pm 1.5$ & $23.4 \pm 23.4$ & $2.89,0.254(\mathrm{NP})$ \\
\hline Conductivity $\left(\mu \mathrm{Scm}^{-1}\right)$ & $410 \pm 271$ & $1,150 \pm 554$ & $1,094 \pm 361$ & $5.91,0.016$ \\
\hline $\mathrm{pH}$ & $8.4 \pm 0.55$ & $7.7 \pm 0.29$ & $7.83 \pm 0.55$ & $2.9,0.094$ \\
\hline Turbidity (NTU) & $113 \pm 41$ & $60 \pm 35$ & $46 \pm 38$ & $2.96,0.09$ \\
\hline $\mathrm{DO}\left(\mathrm{mg} \mathrm{L}^{-1}\right)$ & $8.72 \pm 2.73$ & $5.17 \pm 2.68$ & $4.74 \pm 5.18$ & $36.22,<0.001$ \\
\hline $\mathrm{BOD}_{5}\left(\mathrm{mg} \mathrm{L}^{-1}\right)$ & $8.39 \pm 3.41$ & $21.0 \pm 9.72)$ & $21.8 \pm 10.6$ & $5.94,0.024$ \\
\hline $\operatorname{COD}\left(\mathrm{mg} \mathrm{L}^{-1}\right)$ & $23.8 \pm 17.17$ & $57.0 \pm 42.2$ & $45.4 \pm 31.5$ & $1.73,0.218$ \\
\hline $\mathrm{P}_{-} \mathrm{PO}_{4}^{-}\left(\mathrm{mg} \mathrm{L}^{-1}\right)$ & $0.52 \pm 0.17$ & $2.24 \pm 0.37$ & $2.16 \pm 0.57$ & $9.38,0.009$ \\
\hline $\mathrm{N}-\mathrm{NO}_{2}^{-}\left(\mathrm{mg} \mathrm{L}^{-1}\right)$ & $0.021 \pm 0.02$ & $0.08 \pm 0.06$ & $0.18 \pm 0.09$ & $9.56,0.003$ \\
\hline $\mathrm{N}^{-\mathrm{NO}_{3}}{ }^{-}\left(\mathrm{mg} \mathrm{L}^{-1}\right)$ & $0.52 \pm 0.41$ & $0.55 \pm 0.38$ & $0.92 \pm 0.60$ & $0.9,0.433(\mathrm{NP})$ \\
\hline $\mathrm{N}-\mathrm{NH}_{4}^{+}\left(\mathrm{mg} \mathrm{L}^{-1}\right)$ & $0.09 \pm 0.07$ & $2.34 \pm 1.79$ & $2.53 \pm 1.75$ & $19.3,<0.001$ \\
\hline
\end{tabular}

TSS, total suspended solids; organic TSS, total organic suspended solids; FPOM, fine particulate organic matter; CPOM, coarse particulate organic matter; $D O$, dissolved-oxygen concentration; $B O D_{5}$, biologic oxygen demand; $C O D$, chemical oxygen demand. 
preference for Fungi $(\mathrm{E}=0.96)$. At Site R2, the Tubificinae also did not consume Bacillariophyceae $(E=-0.956)$, while the Megadrili showed a selectivity for Fungi $(E=0.818)$. The dendrogram of Fig. 4 indicates that the groups formed were significant since the highest grouping point was recorded at a similitude of the Shoener index of 0.98 , while another two groups of high similarity could be observed within the subfamilies found in the Carnaval and Rodríguez streams.

The result of the SIMPER analysis indicated that the dissimilitude between the 3 sites of 8.96 was mainly attributable to the detritus since these alimentary items contributed $40 \%$ of the dissimilitude. This item was followed by mineral material at a $32 \%$ contribution (Tab. 4 ). In the Carnaval Stream, the detritus values were lower than those registered at both the Rodríguez sites. Megadrili, Opistocystidae, and Rhyacodrilinae were excluded from the analysis because of the low number of organisms analysed ( $n=1$ for each of those taxa).

\section{DISCUSSION}

The high values of organic matter, nutrients $\left(\mathrm{N}_{-} \mathrm{NH}_{4}{ }^{+}\right.$, $\mathrm{N}-\mathrm{NO}_{3}{ }^{-}, \mathrm{N}-\mathrm{NO}_{2}{ }^{-}, \mathrm{P}-\mathrm{PO}_{4}^{-3}$ ), conductivity, $\mathrm{BOD}_{5}$, and COD along with the low values of DO in the Rodríguez Stream indicate a strong deterioration of the water quality compared to the state of the Carnaval Stream. Although, in general, the pampean streams have a naturally high concentration of nutrients (Feijoo et al., 2005), this characteristic is intensified in the Rodríguez Stream by the input of organic matter related to the human activities developed in the catchment. Because horticulture is carried out within the study area; urea, ammonium sulphate, dibasic ammonium phosphate, ammonium nitrate, and potassium nitrate are the most widely used fertilizers (Hernández and González, 1993). The surrounding area also involves a most intense use of agrochemicals as a result of the great expansion of agriculture within the last 150 years (Rodrigues Capitulo et al., 2010). In addition, both sites of the Rodríguez Stream receive urban and industrial waste

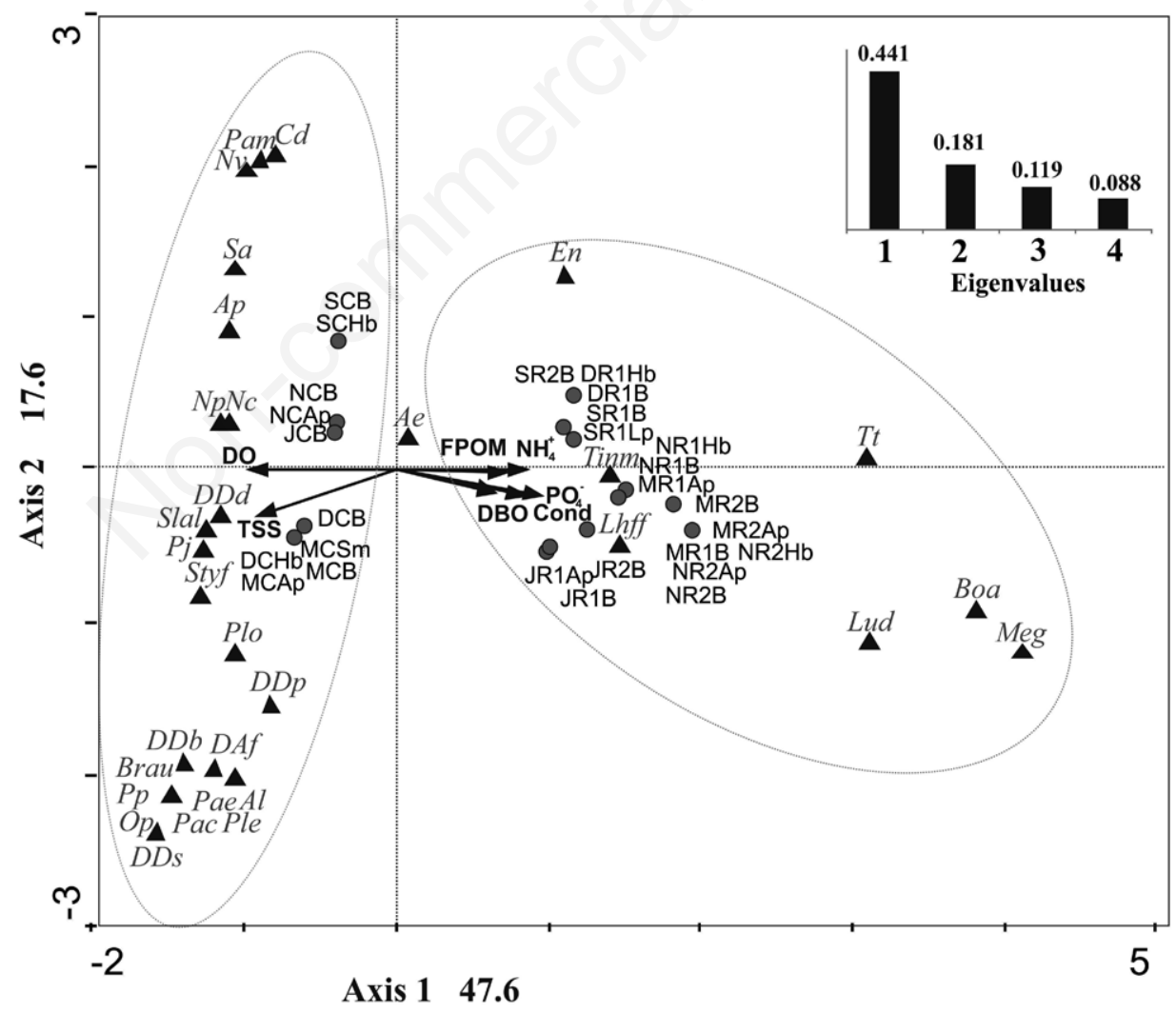

Fig. 2. Canonical-correspondence-analysis ordination of oligochaete species according to the physicochemical parameters at the study sites. Triangles, species ( $c f$. abbreviations in Tab. 2); gray circles, sites. Sampling dates: N, November; M, March; J, June; S, September D, December. C, Carnaval site; R1, Rodríguez Site 1; R2, Rodríguez Site 2. B, benthos; Hb, H. bonariensis; Sm, S. montevidensis; Ap, A. philoxeroides, Lp, L. peploides. Physicochemical parameters: fine particulate organic matter, FPOM; dissolved oxygen, DO; conductivity, Con; phosphate, $\mathrm{P}_{-} \mathrm{PO}_{4}^{-}$; ammonium, $\mathrm{N}_{-} \mathrm{NH}_{4}^{+}$; total suspended solids, TSS. The inset gives the eigenvalues for the four axes. 
plus sewage discharges, all of which contaminants contribute to a deterioration of the water quality (Fernandez and Schnack, 1977; Bauer et al., 2002; Remes Lenicov et al., 2005).The concentration of pesticides varied between the different Rodríguez sampling sites, but only the presence of A-HCH, DDD, and endosulfan (both $\alpha$ and $\beta$ ) were registered in amounts above the threshold levels indicated by the Canadian guidelines. These values had also been observed by Di Marzio et al. (2010) in nearby areas and are consistent with the horticulture performed in the upper reach of the Rodríguez stream (Bauer et al., 2002).

These pesticides could come from either a recent or a previous application, since their persistence in the environment is variable and depends on the ambient conditions leading to their degradation. For example, in sediments, both isomers of endosulfan degrade primarily via microbial biotransformation to endosulfan sulphate (the principal catabolite) along with other minor products. This degradation could be effectively halted, or at least may be considerably slowed, under conditions of low $\mathrm{pH}$ (below 7) or low DO, or in highly organic soils or sediments (CCME, 1975). Alpha-endosulfan disappears quickly in the environment (Eichelberger and Lichtenberg, 1971; Steward and Cairns, 1974), while B-

Tab. 2. Oligochaeta and Aeolosomatidae recorded at the indicated sampling sites (in parentheses) in the streams studied: Carnaval (C) and Rodríguez (R1 and R2) with their average density \pm standard deviation and the number of dissected organisms.

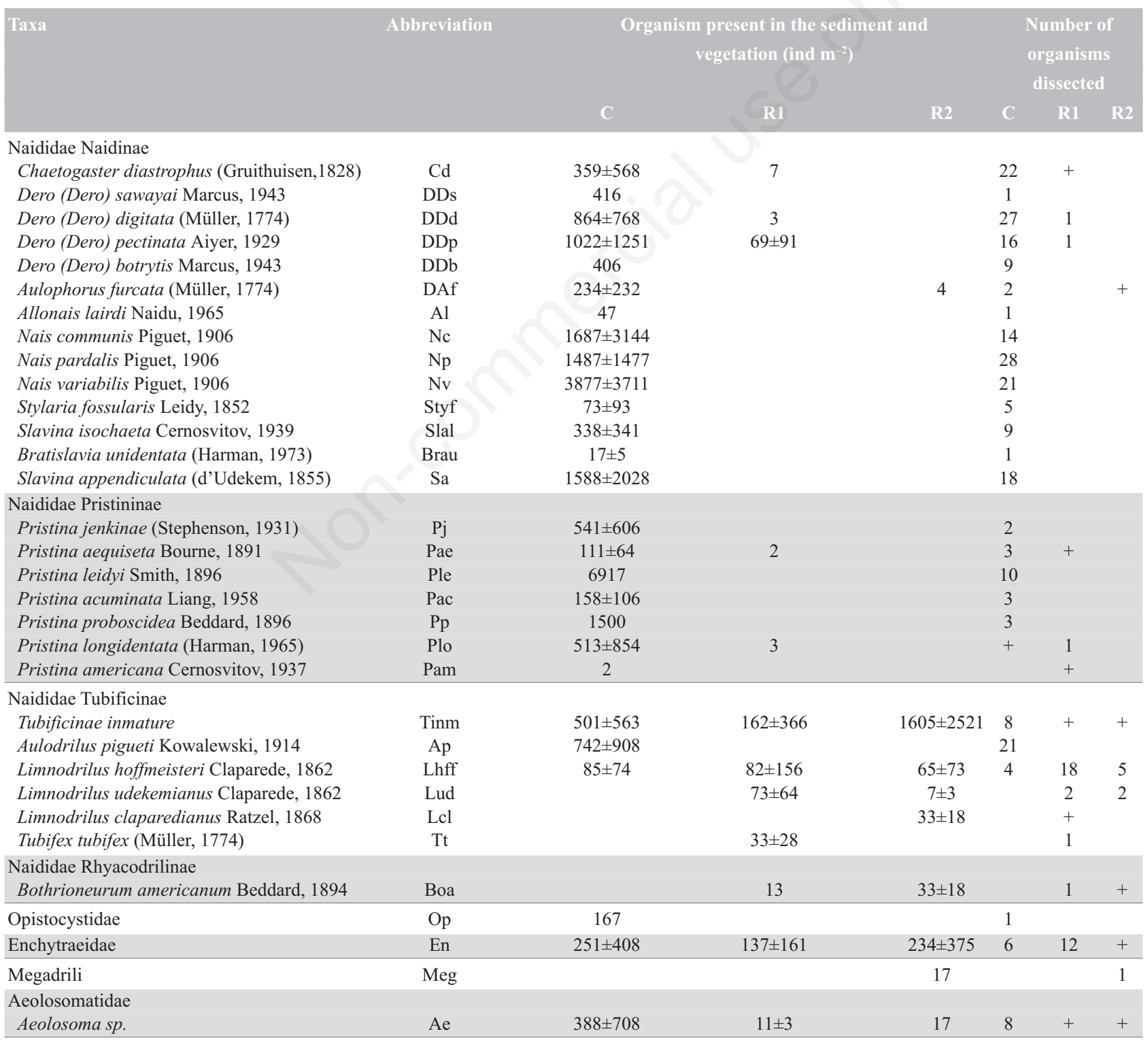

+ , taxa with empty digestive tracts. 
endosulfan and endosulfan sulphate may not completely disappear for over two years (CCME, 1975). The eutrophic environments have anaerobic sediments along with seasonal lows in DO concentrations and could consequently act as sinks for the endosulfans (CCME, 2010). The accumulation of organochlorine pesticides in the sediment could lead to a potential buildup throughout the trophic webs. Many contaminants, because of their largely hydrophobic nature, are strongly associated with the sediments as well as with the dissolved organic matter (Warrena et al., 2003) and therefore can become bioaccumulated in detritivorous organisms, such as the oligochaetes. According to Giarei et al. (2002), T. tubifex and L. hoffmeinsteri rapidly accumulate organochlorides such as A-HCH in their tissues, but the mechanisms have to be better understood to evaluate if this compound can become transferred through the aquatic food webs. Moreover, an anthropic nutrient input can also profoundly change aquatic food webs and ecosystem functioning (Greenwood et al., 2007) and affect the quality of the detritus as a resource, which change could subsequently lead to an altered energy and nutrient flow within detrital food webs (Polis et al., 1997; Vanni et al., 2004; Armendariz et al., 2012). The Rodríguez Stream has higher concentrations of organic matter than the Carnaval owing to the anthropic impact there, which elevation could cause a greater availability of this resource for detritivores (Tomanova et al., 2006; Armendariz et al., 2012).Since organic matter is a basic food source for oligochaetes, their abundance usually increases with elevations in

a
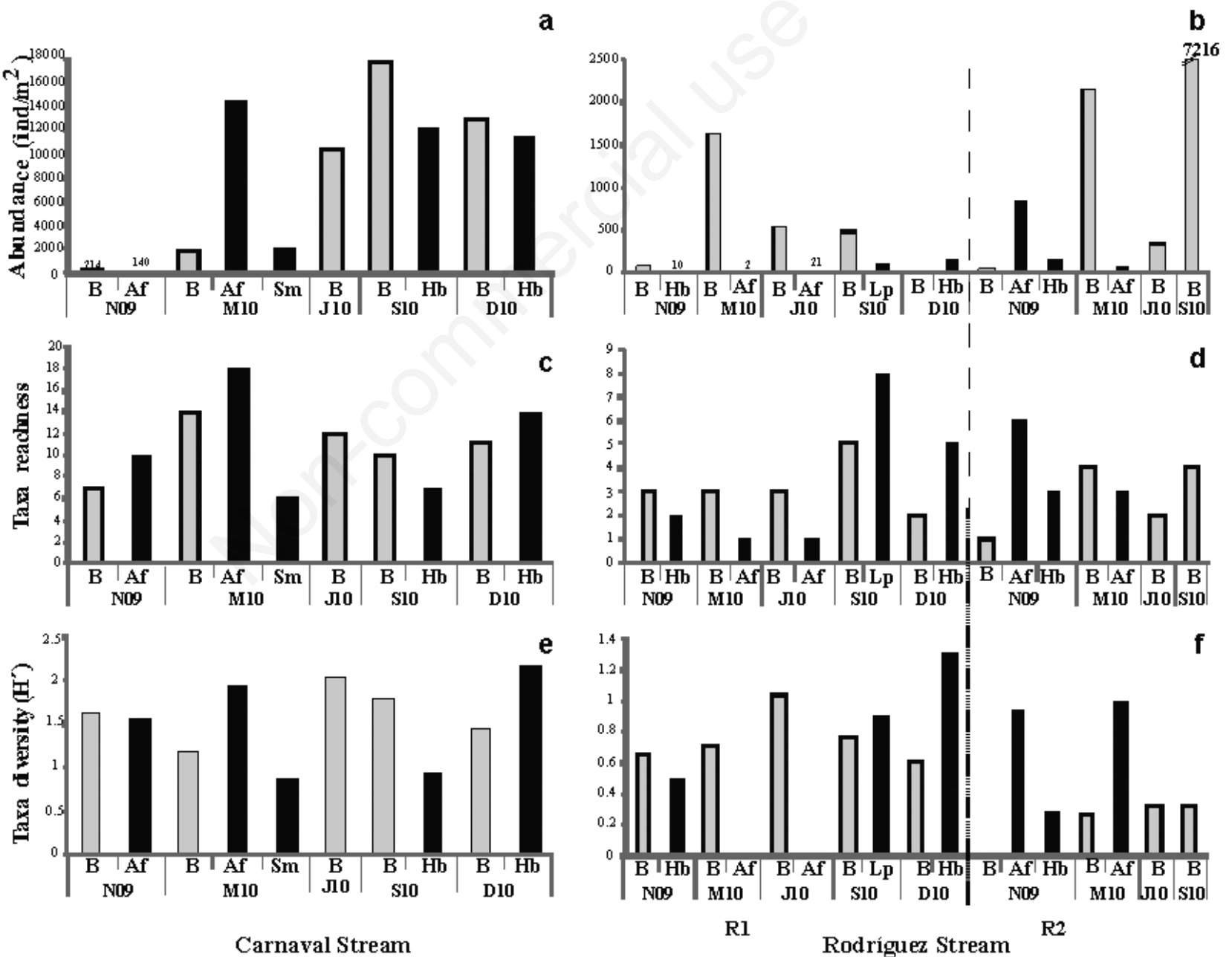

Fig. 3. Total abundance (ind $\mathrm{m}^{-2}$; panels $\mathrm{a}, \mathrm{b}$ ) richness (panels c, d), and diversity (H'; panels e, f) of oligochaetes at three sampling sites in the Carnaval (panels a, c, e; Site C) and Rodríguez (panels b, d, f; sites R1 and R2) streams from November 2009 to December 2010, in two habitats: the sediment of the benthos (B, gray), and the vegetation (black), the latter consisting of H. bonariensis (Hb), S. montevidensis (Sm), A. philoxeroides (Ap), and L. peploides (Lp). 


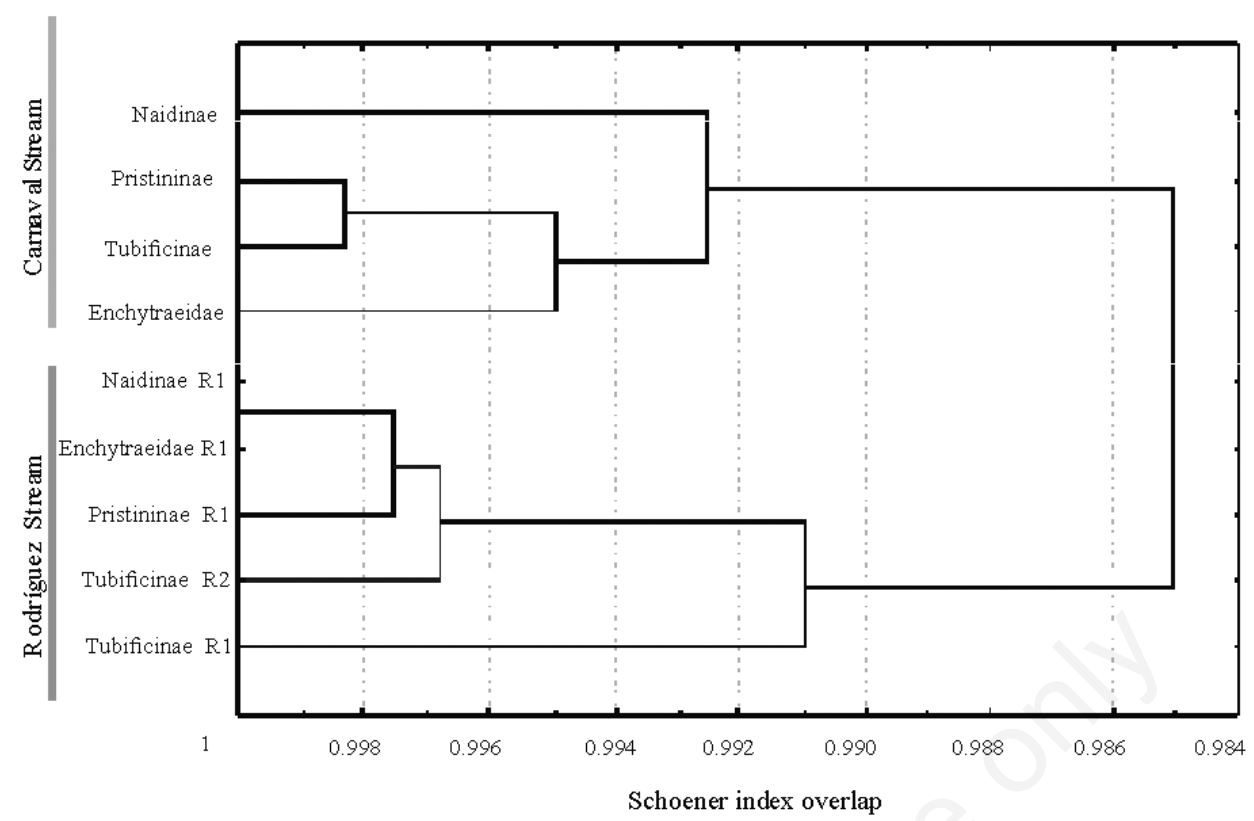

Fig. 4. Dendrogram based on the overlap of dietary profiles between the taxa under investigation through the use of the Schoener index and the complete-linkage method.

Tab. 3. Dietary composition of the recorded oligochaete subfamilies at the Carnaval, Rodríguez 1 and Rodríguez 2 sites expressed as the relative abundance of alimentary items and the percent representation of biofilm taxonomic categories. Those taxonomic categories of biofilm that were ingested by oligochaetes were $\mathrm{Ba}, \mathrm{Fu}, \mathrm{Cl}$ and $\mathrm{Ci}$.

\begin{tabular}{|c|c|c|c|c|c|c|c|c|c|c|c|c|c|c|}
\hline & & & & $\mathrm{Ca}$ & aval & & & & & guez & & & íguez & te 2 \\
\hline & & $\mathrm{Na}$ & $\mathrm{Pr}$ & $\mathrm{Tu}$ & En & Op & Ae & $\mathrm{Na}$ & Pr & Tu & En & $\mathbf{R u}$ & Tu & Me \\
\hline In gut $(\%)$ & & & & & & & & & & & & & & \\
\hline & De & 85.1 & 92.5 & 91.6 & 88 & 100 & 96 & 100 & 97.5 & 91 & 100 & 100 & 96.8 & 98.8 \\
\hline & $\mathrm{Ba}$ & 2.9 & 1 & 0.01 & & & 1.9 & & & 1.8 & & & 0.9 & \\
\hline & $\mathrm{Cl}$ & 0.4 & & & & & & & & & & & & \\
\hline & $\mathrm{Fu}$ & 0.3 & & & & & & & & 7.2 & & & & 1.2 \\
\hline & $\mathrm{Ci}$ & 0.001 & & & & & & & & & & & & \\
\hline & $\mathrm{AR}$ & 1.9 & & & & & & & & & & & & \\
\hline & $\mathrm{OC}$ & 0.03 & & & & & & & & & & & & \\
\hline & Os & 0.1 & & & & & & & & & & & & \\
\hline & Lna & 0.2 & & & & & & & & & & & & \\
\hline & VR & 1.9 & & 0.1 & & & & & 2.5 & & & & & \\
\hline & $\mathrm{Mm}$ & 7.3 & 6.5 & 7.9 & 11.1 & & 2.2 & & & & & & 2.3 & \\
\hline
\end{tabular}

In biofilm $(\%)$

\begin{tabular}{rccccc}
$\mathrm{Ba}$ & 63 & 52 & 40 & 0.12 \\
\hline $\mathrm{Fu}$ & 0.02 & 0.15 & 0.12 \\
$\mathrm{Cl}$ & 4 & 5.7 & 0.46 \\
$\mathrm{Ci}$ & 14 & 0.6 & 1.79 \\
$\mathrm{Eu}$ & 0.21 & 4 & 57.11 \\
$\mathrm{Cy}$ & 18 & 37 & 5 \\
\hline
\end{tabular}

De, Detritus; Ba, Bacillariophyceae; Fu, fungi; Eu, Euglenophyta; Cy, Cyanobacteria; AR, Animal remains; OC, other crustacea; OS, Ostracoda; Lna, nauplius larvae; VR, vegetal remains; Cl, Chlorophyta; Mm, mineral material; and Ci, Ciliata. Na, Naidinae; Pr, Pristininae; Tu, Tubificinae; En, Enchytraeidae; Op, Opistocystidae; Ae, Aeolosomatidae; Ry, Rhyacodrilinae; Me, Megadrili. 
waste concentration (Jablonska, 2014), whereas under such conditions other less resistant organisms disappear.

The present study demonstrates that the Tubificinae (e.g., L. hoffmeisteri, L. udekemianus, Tubifex tubifex), Megadrili, Enchytraeidae, and Rhyacodrilinae were more closely associated with both sites in the Rodríguez Stream, while the Naidinae, Pristininae, and Opistocystidae were more extensively present at the Carnaval site. Similar studies had likewise indicated that the densities of Tubificinae, Enchytraeidae, and Rhyacodrilinae increased with organic pollution; whereas the abundance of Naidinae, Pristininae, and Opistocystidae declined with diminished environmental quality (Alves et al., 2006; Cortelezzi et al., 2012). The Tubificinae exhibit positive correlations with biogenic components such as nitrites, nitrates, and phosphates. $L$. hoffmeisteri and T. tubifex are often used as indicators of organic pollution because of their dominant presence in polluted areas (Verdonschot, 1989; Alves et al., 2006; Jablonska, 2014). This association is consistent with the results reported in the present work, where the most abundant species in the Rodríguez Stream was L. hoffmeisteri, while T. tubifex and L. udekemianus were less prevalent. Furthermore, L. hoffmeisteri is considered the oligochaete species most tolerant to pollution (Verdonschot, 1989). In contrast, $T$. tubifex is particularly vulnerable to competition; and L. udekemianus, though tolerant to poorly oxygenated water, does not usually inhabit highly polluted areas (Milbrink, 1973). As mentioned above, the Naidinae were the most abundant taxa in the Carnaval stream with its more favorable environmental conditions. The most abundant species within this group were $N$. communis, $N$. pardalis, $N$. variabilis, Slavina appendiculata, and $D$. pectinata. Some of these species in particular had been cited by Lin and Yo (2008) as being pollution-intolerant. According to Hynes (1971), benthic environments rich in organic materials support a disproportionately high abun- dance of tolerant oligochaetes. Despite this observation, the abundance in that habitat within the Rodríguez Stream was the lowest (a maximum of $7200 \mathrm{indm}^{-2}$ ). This discrepancy could be attributable to a competition for food between the Tubificinae and the larvae of the diptera Chironomus sp. (Brinkhurst and Kennedy, 1965) since in previous studies the latter was abundant in the Rodríguez Stream (López van Oosterom, 2014).

The results of the dietary analysis indicated that the Tubificinae fed mainly on detritus from all three sites, though lower proportions of Bacillariophyceae and Fungi were also registered. Similar results had been reported by Brinkhurst et al. (1972) and Brinkhurst and Austin (1979). Those authors studied the selective feeding of the tubificids, demonstrated that the organic contents of the feces of T. tubifex and L. hoffmeisteri were significantly higher than the levels present in the sediment, and concluded that the worms fed mainly on the organic-rich fraction of the sediment. The Naidinae consumed a higher number of food items in Carnaval Stream. According to Wachs (1967), Streit (1977), Learner et al. (1978), McElhone (1979), Bowker et al. (1983); this subfamily ingests a wide variety of materials including sand grains, detritus, algae, and conifer pollen. C. diastrophus was the only predaceous species, as evidenced by the presence of Crustacea in its gut contents. In this species other detritus plus algae (e.g., Bacillariophyceae, Chlorophyta) were also found in accordance with the observations by Wachs (1967) and Streit (1977). The functional parameters studied indicated a high dietary overlap because all the species analyzed consumed a high proportion of detritus according to the values obtained by Schoener's Proportional Similitude Index. The results of SIMPER analyses indicated that the principal difference in oligochaete diet between the two streams was with respect to the food item detritus, with the organisms of the Rodríguez sites

Tab. 4. Percent contribution to dissimilitude (SIMPER) of the alimentary items observed in the three sites studied (C in the Carnaval Stream; R1 and R2 in the Rodríguez Stream).

\begin{tabular}{|c|c|c|c|c|c|c|}
\hline Items & Average of dissimilitude & Contribution (\%) & Cumulative (\%) & C & R1 & R2 \\
\hline De & 3.59 & 40.1 & 40.1 & 0.893 & 0.971 & 0.968 \\
\hline $\mathrm{Mm}$ & 3.42 & 38.2 & 78.3 & 0.082 & 0 & 0.023 \\
\hline $\mathrm{Fu}$ & 0.770 & 8.59 & 86.9 & 0.00075 & 0.018 & 0 \\
\hline $\mathrm{Ba}$ & 0.515 & 5.75 & 92.6 & 0.00978 & 0.0045 & 0.009 \\
\hline VR & 0.386 & 4.30 & 96.9 & 0.005 & 0.00625 & 0 \\
\hline $\mathrm{AR}$ & 0.198 & 2.21 & 99.2 & 0.00475 & 0 & 0 \\
\hline $\mathrm{Cl}$ & 0.0416 & 0.465 & 99.6 & 0.001 & 0 & 0 \\
\hline Lna & 0.0208 & 0.232 & 99.9 & 0.0005 & 0 & 0 \\
\hline Os & 0.0104 & 0.116 & 100 & 0.00025 & 0 & 0 \\
\hline $\mathrm{OC}$ & 0.00312 & 0.0349 & 100 & 0.00075 & 0 & 0 \\
\hline
\end{tabular}

De, detritus; Mm, mineral material; Fu, fungi; Ba, Bacillariophyceae; VR, vegetal remains; AR, animal remains; Cl, Chlorophyta; Lna, nauplius larvae; Os, Ostracods; OC, other crustacea. 
evidencing a higher percentage of detritus in the gut contents than those of the Carnaval site. Oligochaetes are most commonly classified as gathering collectors (Cummins et al., 2005), which category implies that they feed on fine particles of organic matter as well as on the associated microorganisms, especially the hyphomycetes fungi (Suberkropp et al., 1983). In our study, the electivity index indicated that the Naidinae in the Carnaval Stream and the Tubificinae in the Rodríguez Stream preferred Fungi, while none of the taxa preferred Bacillariophyceae and Chlorophytes. According to Naiman and Bilby (2001), fungal colonization of coarse particulate organic matter affects both the palatability and the nutritional quality of the detritus. In the Neotropical Region the detritus is a fundamental food resource for the macroinvertebrates in the trophic networks of freshwater ecosystems (Tomanova et al., 2006; Ocon et al., 2013 and Lopez van Oosterom et al., 2013). The detritivores are more abundant in environments with high organic pollution since that functional-feeding group is involved in the recycling of nutritive matter and energy (Rodriguez and Reynoldson, 2011).

\section{CONCLUSIONS}

In the studied streams, the oligochaetes responded to pollution with changes in their structural patterns. At the same time, these worms consumed high amounts of detritus, which dietary preference enables the Oligocheta to play a fundamental role in the food webs of freshwater ecosystems since those organisms therefore establish a link between detritus as a basal resource and the higher trophic levels. A joint study of the structural and functional patterns of food-web organisms with an aim at achieving a better understanding of the processes affecting the dynamics of aquatic systems is essential for the development of a more comprehensive approach to a relevant sustainable management of those environments.

\section{ACKNOWLEDGEMENTS}

This study was supported by the CONICET (PIP 0341). This is Scientific Contribution $N^{\circ} 955$ from the Dr. Raúl A. Ringuelet Instituto de Limnología (CONICET La Plata-UNLP). We wish to thank Monica Caviglia for editing the draft of the manuscript. The final version was edited by Dr. Donald F. Haggerty, a retired career investigator and native English speaker. The authors are also grateful to Jorge Donadelli, from the Laboratory of Chemistry of the ILPLA, for the nutrient and oxygen-demand analyses of the water samples.

\section{REFERENCES}

AA-AGOSBA-ILPLA-SHN, 1997. [Calidad de las aguas. Franja Costera Sur del Río de la Plata (San Fernando-Mag-
dalena)].[Report in Spanish]. Consejo Permanente para el Monitoreo de la Calidad de las Aguas de la Franja Costera Sur del Río de la Plata, Buenos Aires, Argentina.

Alves RG, Marchese MR, Escarpinati SC, 2006. Oligochaeta (Annelida, Clitellata) in lotic environments in the state of São Paulo, Brazil. Iheringia Ser Zool. 96:431-435.

APHA, 1989. Standard methods for the examination of water and wastewater, $17^{\text {th }}$ edition, Washington DC, USA: $1268 \mathrm{pp}$.

APHA, 1998. Standard methods for the examination of water and wastewater, $20^{\text {th }}$ edition, Washington DC, USA: $1220 \mathrm{pp}$.

Armendáriz L, Ocón C, Rodrigues Capítulo A, 2012. Potential responses of oligochaetes (Annelida, Clitellata) to global changes: Experimental fertilization in a lowland stream of Argentina (South America). Limnologica 42:118-126.

Azrina MZ, Yap CK, Rahim Ismail A, Ismail A, Tan SG, 2006. Anthropogenic impact on the distribution and biodiversity of benthic macroinvertebrates and water quality of the Langat River, Peninsular Malaysia. Ecotox. Environ. Safe. 64:337-47.

Banda Noriega RB, Ruiz de Galarreta A, 2002. [Riesgo de contaminación hídrica subterránea por la actividad industrial, cuenca de los arroyos Martín y Carnaval, Buenos Aires, Argentina, p. 153-162].[Article in Spanish]. In: E. Bocanegra, D. Martínez and H. Massone (eds.), Groundwater and human development. Proceedings XXXII IAH and VI ALHSUD Congress, Mar del Plata, Argentina.

Barbour MT, Gerritsen J, Snyder BD, Stribling JB, 1999. Rapid bioassessment protocols for use in streams and wadeable rivers. Periphyton, benthic macroinvertebrates and fish. 2. U.S. Environmental Protection Agency; Office of Water; Washington: $326 \mathrm{pp}$.

Bauer DE, Conde ME, Gómez N, 2002. Phytoplankton of a small lowland stream related to water quality and hydraulic discontinuities. Arch. Hydrobiol. 153:421-442.

Bletter M, Amsler M, Ezcurra de Drago I, Marchese M, 2008. Effects of stream hydraulics and other environmental variables on density of Narapa bonettoi (Oligochaeta) in the Paraná River system. River Res. Appl. 24:1124-1140.

Bowker DW, Wareham MT, Learner MA, 1983. The selection and ingestion of epilithic algae by Nais elinguis (Oligochaeta: Naididae). Hydrobiologia 98:171-178.

Brinkhurst RO, Kennedy CR, 1965. Studies on the biology of the Tubificidae (Annelida, Oligochaeta) in a polluted stream. J. Anim. Ecol. 34:429-443.

Brinkhurst RO, Chua KE, Kaushik NK, 1972. Interspecific interactions and selective feeding by tubificid oligochaetes. Limnol. Oceanogr. 17:122-133.

Brinkhurst RO, Austin MJ, 1979. Assimilation by aquatic oligochaeta. Int. Rev. Hydrobiol. 64:245-250.

Brinkhurst RO, Marchese MR, 1992. [Guía para la identificación de oligoquetos acuáticos continentales de sud y centroamérica].[Book in Spanish]. Associación de Ciencias Naturales del Litoral, Santo Tomé: 207 pp.

Cabrera A, 1971. [Fitogeografía de América Latina].[Article in Spanish]. Bol. Soc. Argent. Bot. 14:1-42.

CCME, Canadian Council of Ministers of the Environment, 2003. Canadian Environmental Quality Guidelines. A protocol for the derivation of water quality guidelines for the protection of aquatic life. Available from: http://ceqg-rcqe.ccme.ca

CCME, Canadian Council of Ministers of the Environment, 2010. Canadian Environmental Quality Guidelines, Scien- 
tific Criteria Document - Canadian Water Quality Guidelines - For Endosulfan. Available from: http://ceqg-rcqe.ccme.ca

Clarke KR, Warwick RM, 2001. Change in marine communities: an approach to statistical analysis and interpretation. 2. Plymouth, UK: $250 \mathrm{pp}$.

Collado R, Schmelz RM, 2001. Oligochaete distribution patterns in two german hardwater lakes of different trophic state. Limnologica 31:317-328.

Cortelezzi A, Armendáriz LC, López van Oosterom, MV, Cepeda R, Rodrigues Capítulo A, 2012. Different levels of taxonomic resolution in bioassessment: a case study of Oligochaeta in lowland streams. Acta limnol. Bras. 23:1-14.

Cummins KW, Merritt RW, Andrade PCN, 2005. The use of invertebrate functional groups to characterize ecosystem attributes in selected streams and rivers in south Brazil. Stud. Neotrop. Fauna E. 40:69-89.

Díaz-Villanueva V, Albariño R, 1999. Feeding habit of Notoperla archiplatae (Plecoptera) larvae in a North Patagonia Andean stream, Argentina. Hydrobiologia 412:43-52.

Darrigran G, Martín S, Gullo B, Armendáriz L, 1998. Macroinvertebrates associated with Limnoperna fortunei (Dunker, 1857) (Bivalvia, Mytilidae) in Río de la Plata, Argentina. Hydrobiologia 367:223-230.

Di Marzio WD, Sáenz ME, Alberdi JL, Fortunato N, Cappello V, Montivero C, Ambrini G, 2010. Environmental impact of insecticides applied on biotech soybean crops in relation to the distance from aquatic ecosystems. Environ. Toxicol. Chem. 29:1907-1917.

Eichelberger JW, Lichtenberg JJ, 1971. Persistence of pesticides in river waters. Environ. Sci. Technol. 5:541-544.

EPA, Environmental Protection Agency, 1995. Environmental monitoring and assessment program for surface waters: field operations and methods for measuring the ecological condition of wadeable streams. Office of Research and Development, US Environmental Protection Agency, Washington: $447 \mathrm{pp}$.

Ezcurra de Drago I, Marchese M, Montalto L, 2007. Benthic invertebrates, p. 251-271. In: M. Iriondo, JC Paggi, JE Parma (eds.), The middle Paraná River: limnology of subtropical wetland. Springer, Heidelberg.

Feijóo CS, Menéndez M, 2009. [La biota de los ríos: macrófitos, p. 240-247]. In: A. Elosegi and S. Sabater (eds.), [Conceptos y técnicas para el estudio de la ecología de ríos].[Book in Spanish]. Fundación BBVA.

Feijoó CS, Rigacci L, Doyle S, 2005. Ecological regionalization of pampean streams in Argentina. Verh. Internat. Verein. Limnol. 29:748-753.

Ferreiro N, Feijoó C, Giorgi A, Leggieri L, 2011. Effects of macrophyte heterogeneity and food availability on structural parameters of the macroinvertebrate community in a Pampean stream. Hydrobiologia 664:199-211.

Fernández L, Schnack JA, 1977. [Estudio preliminar de la fauna bentónica en tramos poluídos de los arroyos Rodríguez y Carnaval (Provincia de Buenos Aires)].[Article in Spanish]. ECOSUR 4:103-115.

Folk RL, 1959. Practical petrographic classification of limestones. AAPG Bull. 43:1-38.

Giorgi A, Feijoó C, Tell G, 2005. Primary producers in a pampean stream: temporal variation and structuring role. Biodivers. Conserv. 14:1699-1718.
Gómez N, Licursi M, 2001. The pampean diatom index (IDP) for assessment of rivers and streams in argentina. Aquat. Ecol. 35:173-181.

Greenwood JL, Rosemond AD, Wallace JB, Cross WF, Weyers HS, 2007. Nutrients stimulate leaf breakdown rates and detritivore biomass: bottom-up effects via heterotrophic pathways. Oecologia 151:637-649.

Hammer Ø, Harper DAT, Ryan PD, 2001. Past: paleontological statistics software package for education and data analysis. Palaeontologia Electronica 4:19-20.

Hernandez MA, Gonzalez N, 1993. [Recursos hídricos y ambiente, p. 175-184]. In: F. Goin and R. Goñi (eds.), [Elementos de política ambiental].[Book in Spanish]. Di Giovanni, La Plata.

Hynes HBN, 1971. The biology of polluted waters. University of Toronto Press: 202 pp.

International Commission on Zoological Nomenclature, 2007. Bulletin of zoological nomenclature. Opinion 2167.

Ivlev VS, 1961. Experimental ecology of the feeding of fishes. Yale University Press, New Haven: 302 pp.

Jabłońska A, 2014. Oligochaete communities of highly degraded urban streams in Poland, Central Europe. North-West J. Zool. 10:74-82.

Jouravlev A, 2001. [Administración del agua en América Latina y el Caribe en el umbral del siglo XXI].[Report in Spanish]. CEPAL, Santiago: 77 pp.

Kaika M, Page B, 2003. EU water framework directive: part 1. European policy-making and the changing topography of lobbying. Eur. Env. 13: 314-327.

Krezoski JR, Robbins JA, 1985. Vertical distribution of feeding and particle-selective transport of ${ }^{137} \mathrm{Cs}$ in lake sediments by lumbriculid oligochaetes. J. Geophys. Res. Oceans 90: 11999-12006.

Krodkiewska M, Michalik-Kucharz A, 2009. The bottom Oligochaeta communities in sand pits of different trophic status in Upper Silesia (Southern Poland). Aquat. Ecol. 43:437-444.

Lafont M, Camus JC, Fournier A, Sourp E, 2001. A practical concept for the ecological assessment of aquatic ecosystems: application on the River Dore in France. Aquat. Ecol. 35:195-205.

Learner MA, Lockhead G, Hughes BD, 1978. A review of the biology of British Naididae (Oligochaeta) with emphasis on the lotic environment. Freshwater Biol. 8:357-375.

Lin KJ, Yo SP, 2008. The effect of organic pollution on the abundance and distribution of aquatic oligochaetes in an urban water basin, Taiwan. Hydrobiologia 596:213-223.

López van Oosterom MV, Ocon CS, Bracolini F, Maroñas M, Sendra E, Rodrigues Capitulo A, 2013. Trophic relationships between macroinvertebrates and fish in a pampean lowland stream (Argentina). Iheringia. Ser. Zool. 03:57-65.

López van Oosterom MV, 2014. [Relaciones tróficas de los principales macroinvertebrados en sistemas lóticos de la llanura pampeana: su relación con la calidad del agua]. [PhD Thesis in Spanish]. Repositorio Institucional de la Facultad de Ciencias Naturales y Museo (UNLP).

Marchese M, 2009. [Annelida Oligochaeta, p 551-565]. In: E. Dominguez, and H.R. Fernandez (eds.), [Macroinvertebrados bentónicos sudamericanos: sistemática y biología].[Book in Spanish]. Fundación Miguel Lillo, Tucumán.

Martin P, Martínez-Ansemil E, Pinder A, Timm T, Wetzel MJ, 
2008. Global diversity of oligochaetous clitellates ("Oligochaeta"; Clitellata) in freshwater. Hydrobiologia 595:17-127.

McElhone MJ, 1979. A comparison of the gut contents of two co-existing lake-dwelling Naididae (Oligochaeta), Nais pseudobtusa and Chaetogaster diastrophus. Freshwater Biol. 9:199-204.

Metcalfe-Smith JL, 1996. Biological water quality assessment of rivers: use of macroinvertebrate communities, p. 144-170. In: P. Calow, and G.E. Petts (eds.), The rivers handbook: hydrological and ecological principles. Blackwell, Oxford.

Milbrink G, 1973. On the use of indicator communities of Tubificidae and some Lumbriculidae in the assessment of water polluition in Swedish lakes. Zoon. 1:125-139.

Motta RL, Uieda VS, 2004. Diet and trophic groups of an aquatic insect community in a tropical stream. Braz. J. Biol. 64:809-817.

Naiman RJ, Bilby RE, 2001. River ecology and management: lessons from the Pacific coastal ecoregion. Springer, New York: $689 \mathrm{pp}$.

NRCC, 1975. Endosulfan: its effects on environmental quality. National Research Council Canada Publications, Ottawa: $100 \mathrm{pp}$.

Nijboer RC, Wetzel MJ, Verdonschot PFM, 2004. Diversity and distribution of Tubificidae, Naididae and Lumbriculidae (Annelida: Oligochaeta) in the Netherlands: an evaluation of twenty years of monitoring data. Hydrobiologia 520:127-141.

Ocon C, Lopez-van Oosterom MV, Muñoz MI, Rodrigues Capítulo A, 2013. Macroinvertebrate trophic responses to nutrient addition in a temperate stream in South America. Fund. Appl. Limnol. 182:17-30.

Pasteris A, Bonacina C, Bonomi G, 1994. Observations on cohorts of Tubifex tubifex cultured at different food levels, using cellulose substrate. Hydrobiologia 278:315-320.

Polis GA, Anderson WB, Holt RD, 1997. Toward an integration of landscape and food web ecology: the dynamics of spatially subsidized food webs. Annu. Rev. Ecol. Evol. S. 28:289-316.

Remes Lenicov M, Colautti DC, López HL, 2005. [Ictiofauna de un ambiente lótico suburbano: el arroyo Rodríguez (Buenos Aires, Argentina)].[Article in Spanish]. Biología Acuática 22:223-230.

Rodrigues Capítulo A, Gómez N, Giorgi A, Feijoo C, 2010. Global changes in pampean lowland streams (Argentina): implications for biodiversity and functioning. Hydrobiologia 657:53-70.

Rodriguez P, Martinez-Madrid M, Arrate AJ, Navarro E, 2001. Selective feeding by the aquatic oligochaete Tubifex tubifex (Tubificidae, Clitellata). Hydrobiologia 463:133-140.

Rodriguez P, Reynoldson TB, 2011. The pollution biology of aquatic Oligochaetes. Springer, New York: 263 pp.
Rublee PA, Partusch-Talley A, 1995. Microfaunal response to fertilization of an artic tundra. Freshwater Biol. 34:81-90.

Schoener TW, 1970. Nonsynchronous spatial overlap of lizards in patchy habitats. Ecology 51:408-418.

Sokal RR, Rohlf FJ, 1995. Biometry: the principles and practice of statistics in biological research. 3. W. H. Freeman \& Co., New York: 887 pp.

Steward DKR, Cairns KG, 1974. Endosulfan persistence in soil and uptake by potato tubers. J. Agr. Food Chem. 22: 984-986.

Streit B, 1977. Morphometric relationships and feeding habits of two species of Chaetogaster, Ch. limnaei and Ch. diastrophus (Oligochaeta). Arch. Hydrobiol. Suppl. 48: 424-437.

Suberkropp K, Arsuffi TL, Anderson JP, 1983. Comparison of degradative ability, enzymatic activity, and palatability of aquatic hyphomycetes grown on leaf litter. Appl. Environ. Microb. 46:237-244.

Ter Braak CJF, Smilauer P, 2002. CANOCO reference manual and CanoDraw for Windows user's guide: software for canonical community ordination (ver. 4.5). Microcomputer Power, Ithaca.

Tomanova S, Goitia E, Helešic J, 2006. Trophic levels and functional feeding groups of macroinvertebrates in neotropical streams. Hydrobiologia 556:251-264.

Vanni MJ, De Angelis DL, Schindler DE, Huxel GR, 2004. Overview: cross-habitat flux of nutrients and detritus, p. 311. In: G.A. Polis, M.E. Power and G.R. Huxel (eds.), Food webs at the landscape level. University of Chicago Press.

Verdonschot PFM, 1989. The role of oligochaetes in the management of waters. Hydrobiologia 180:213-227.

Wachs B, 1967. [Die Oligochaeten-Fauna der Fliessgewasser unter besonderer beriicksichtigung der Beziehungen zwischen der Tubificiden-Bessiedlung und dem Substrat].[Article in Gemran]. Archiv Hydrobiol. 63:310-386.

Wallace RK Jr, 1981. An assessment of diet-overlap indices. T. Am. Fish. Soc. 110:72-76.

Warfe DM, Barmuta LA, 2006. Habitat structural complexity mediates food web dynamics in a freshwater macrophyte community. Oecologia 150:141-154.

Warrena N, Allana IJ, Carterc JE, Houseb WA, Parkera A, 2003. Pesticides and other micro-organic contaminants in freshwater sedimentary environments - A review. Appl. Geochem. 18:159-194

Wetzel MJ, Fend S, Coates KA, Kathman RD, Gelder SR, 2006. Taxonomy, systematic and ecology of the aquatic Oligochaeta and Branchiobdellida (Annelida, Clitellata) of North America, with emphasis of the fauna occurring in Florida: a workbook. Florida Department of Environmental Protection: 269 pp. 